\title{
Phylogeography and postglacial recolonization of Europe by Rhinolophus hipposideros: evidence from multiple genetic markers
}

\author{
SERENA E. DOOL, * SÉBASTIEN J. PUECHMAILLE, ${ }^{\dagger}+$ CHRISTIAN DIETZ,§ JAVIER JUSTE, $\uparrow$ \\ CARLOS IBÁÑEZ, ๆ PAVEL HULVA, ${ }^{*}+\dagger$ STÉPHANE G. ROUÉ,ł+ ERIC J. PETIT, $\S$

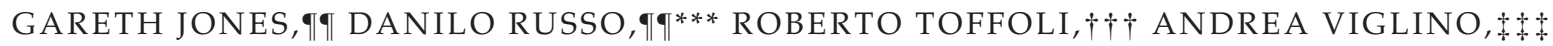

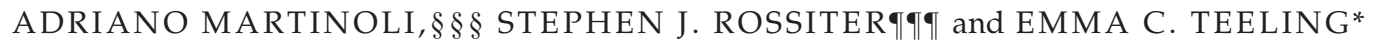 \\ *School of Biology and Environmental Science, University College Dublin, Belfield, Dublin 4, Ireland, †Sensory Ecology Group, \\ Max Planck Institute for Ornithology, 82319, Seewiesen, Germany, \$Midi-Pyrénées bat group (CREN-GCMP), Toulouse, France, \\ §Animal Physiology, Zoological Institute, Tübingen University, Auf der Morgenstelle 28, Tübingen 72076, Germany, $\mid$ Doñana \\ Biological Station (CSIC), Avda. Americo Vespucio s/n, Isla de la Cartuja, Seville 41092, Spain, **Department of Zoology, \\ Faculty of Science, Charles University in Prague, Viničná 7, Praha 2128 44, Czech Republic, ††Life Science Research Centre, \\ University of Ostrava, Chittussiho 10, Ostrava 710 00, Czech Republic, \$tSociété d'histoire naturelle d'Autun, Maison du Parc, \\ Saint-Brisson 58230, France, §§University Rennes 1/CNRS, UMR 6553 ECOBIO, Station Biologique, Paimpont 35380, France, \\ qTSchool of Biological Sciences, University of Bristol, Woodland Road, Bristol, BS8 1UG, UK, ***Dipartimento di Agraria, \\ Laboratorio di Ecologia Applicata, Università degli Studi di Napoli Federico II, via Università 100, 80055 Portici (Napoli), Italy, \\ ††Consulenze Faunistiche, Via P. Viada 3/B 12011 Roccavione, CN, Italy, \$\$ISPRA (Istituto Superiore per la Protezione e la \\ Ricerca Ambientale), Via Ca' Fornacetta 9, Ozzano Emilia (BO) 40064, Italy, §§§Department of Theoretical and Applied Sciences, \\ Environment Analysis and Management Unit, University of Insubria, Via Dunant, Varese 3 I-21100, Italy, $\mathbf{9 \uparrow \uparrow S c h o o l ~ o f ~}$ \\ Biological and Chemical Sciences, Queen Mary University of London, Fogg Building, Mile End Road, London, E1 4NS, U.K
}

\begin{abstract}
The demographic history of Rhinolophus hipposideros (lesser horseshoe bat) was reconstructed across its European, North African and Middle-Eastern distribution prior to, during and following the most recent glaciations by generating and analysing a multimarker data set. This data set consisted of an X-linked nuclear intron (Bgn; $543 \mathrm{bp}$ ), mitochondrial DNA (cytb-tRNA-control region; $1630 \mathrm{bp}$ ) and eight variable microsatellite loci for up to 373 individuals from 86 localities. Using this data set of diverse markers, it was possible to determine the species' demography at three temporal stages. Nuclear intron data revealed early colonization into Europe from the east, which pre-dates the Quaternary glaciations. The mtDNA data supported multiple glacial refugia across the Mediterranean, the largest of which were found in the IberoMaghreb region and an eastern location (Anatolia/Middle East)-that were used by $R$. hipposideros during the most recent glacial cycles. Finally, microsatellites provided the most recent information on these species' movements since the Last Glacial Maximum and suggested that lineages that had diverged into glacial refugia, such as in the Ibero-Maghreb region, have remained isolated. These findings should be used to inform future conservation management strategies for $R$. hipposideros and show the power of using a multimarker data set for phylogeographic studies.
\end{abstract}

Keywords: Anatolia, Chiroptera, glacial refugia, Maghreb, Quaternary ice ages, Western Palearctic

Correspondence: Dr. Emma C. Teeling, Fax: +353 1716 1152;

E-mail: emma.teeling@ucd.ie; Dr. Stephen J. Rossiter, Fax: +44

207882 7732; E-mail: s.j.rossiter@qmul.ac.uk 


\section{Introduction}

Well-supported phylogeographic inferences linked to past climatic events provide a powerful tool for predicting how future climatic changes will influence regional biodiversity, which is a grand challenge in modern biology (Petit et al. 2005; Hickerson et al. 2010; Eckert 2011). Europe during the Quaternary ice ages experienced massive and intense climate fluctuations culminating in the Last Glacial Maximum (LGM 18-20 kyr, Strandberg et al. 2011). The far-reaching consequences of these climatic changes on species richness and biodiversity are well documented (Emerson \& Hewitt 2005), as is the role played by the Mediterranean peninsulas as the main, but not exclusive refugia used by European biota during glacial periods (Hewitt 1999). Following climate warming during the Holocene, species that survived in refugia expanded northwards giving rise to the current phylogeographic structuring of populations (Hewitt 2004). In addition to the Mediterranean refugia, recent studies of diverse taxa have suggested the presence of refugia-within-refugia (Ursenbacher et al. 2008; CentenoCuadros et al. 2009) and additional cryptic or microrefugia (Bilton et al. 1998; Cosson et al. 2005; Kotlik et al. 2006). These results illustrate the diversity of species-specific responses to climate change, highlighting the need for a multitaxa approach to better predict a biological community's response to climate change (Bermingham \& Moritz 1998; Arbogast \& Kenagy 2001). Elucidating the recolonization history of many European taxa that exist in diverse ecological niches will better inform our understanding of the impacts of future climate change on European biodiversity (Petit et al. 2005; Hickerson et al. 2010; Eckert 2011). It is predicted that bats with a current Mediterranean distribution, including $R$. hipposideros, will initially expand their distributions northwards during the coming decades, but will suffer major extinctions in southern Europe by the end of the century (Rebelo et al. 2010).

Rhinolophus hipposideros is the smallest (6-9 g) of the five horseshoe bat species which occur in Europe (Dietz et al. 2009). R. hipposideros is geographically widespread, found throughout the continent of Europe from Ireland in the northwest to Pakistan in the east, and south into northern regions of Africa and Saudi Arabia (Fig. 1, Jacobs et al. 2008). There are several proposed subspecies mainly based on morphological characters (Palmeirim 1990; Csorba et al. 2003) and several karyotypic variants within this species have been described (Zima et al. 1992). R. hipposideros is classified as Near Threatened within Europe by the IUCN (Jacobs et al. 2008) and in the EU Habitats and Species Directive (Annexes II \& IV) due to sudden and drastic recent population declines in north-central Europe (Mitchell-Jones 1995). This species has a long fossil history within Europe dating back to the Pliocene (Storch 1974; Payne 1983); however, nothing is known about its phylogeographic history. The only other Rhinolophus species with a similar range in Europe is $R$. ferrumequinum (greater horseshoe bat). Whilst these species are not phylogenetically

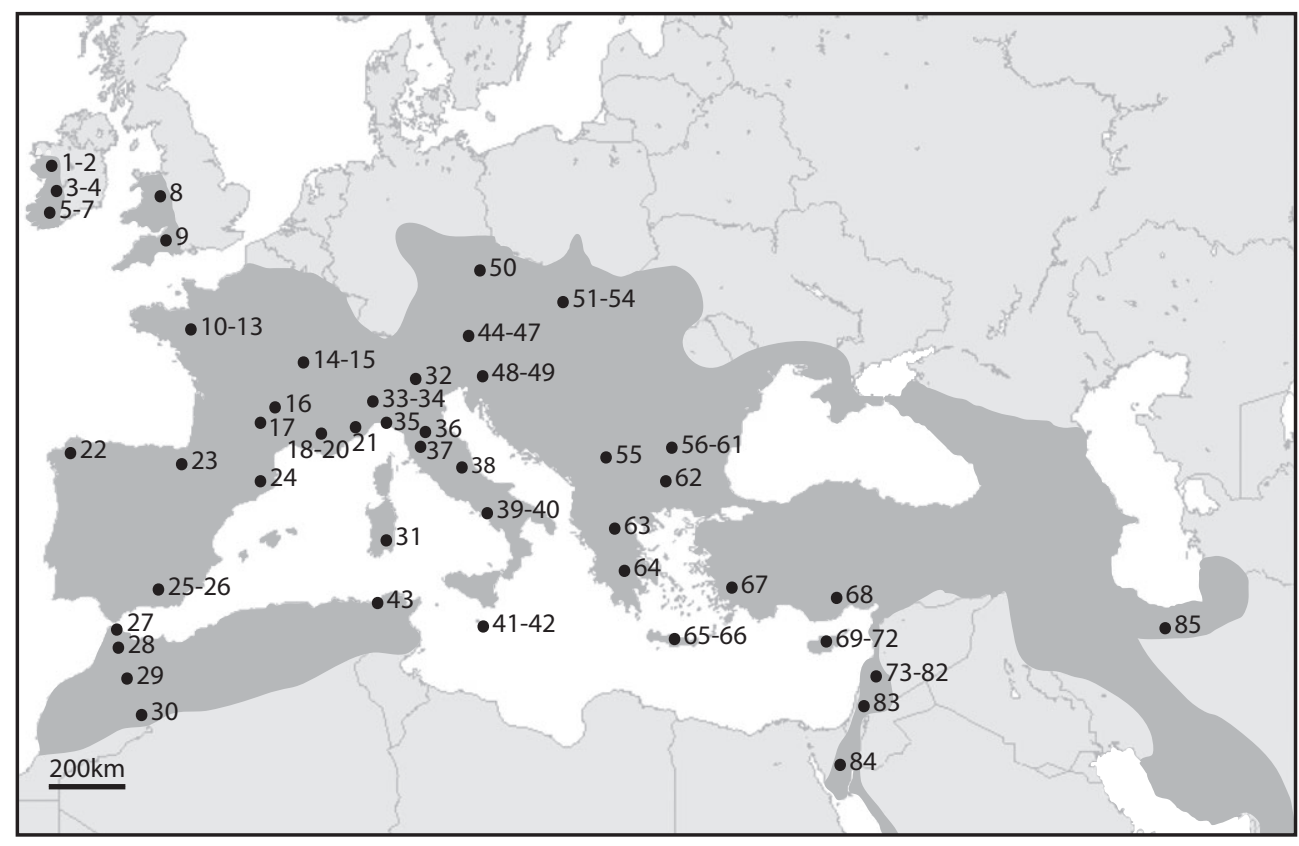

Fig. 1 Sampling localities for Rhinolophus hipposideros used in the current phylogeographic study. Proximal localities are marked as a single point. Tajikistan (site 86, Table 1) not shown. Species distribution based on Jacobs et al. (2008) shown in dark grey. 
close within the Rhinolophidae, they arguably share similar ecological needs and thus may have responded similarly to environmental changes, resulting in shared demographic histories. Phylogeographic studies of $R$. ferrumequinum showed that this species used refugia in both western Europe (Iberia and/or Italy) and eastern Europe (Balkans/Greece), and also used other more ancient refugia pre-dating the LGM in Asia Minor (Rossiter et al. 2007; Bilgin et al. 2009; Flanders et al. 2009) and further east (Flanders et al. 2009, 2011).

Since the advent of phylogeography, mitochondrial DNA has been the marker of choice for animal studies. However, numerous recent studies have questioned the assumptions underlying the use of this marker and the validity of phylogeographic reconstructions when based solely on mtDNA (Hurst \& Jiggins 2005; Galtier et al. 2009; Balloux 2010). Other molecular markers typically used in population-based phylogeography are microsatellites (Rossiter et al. 2007; Earl et al. 2010) and less frequently, nuclear introns (Martins et al. 2009; Spinks et al. 2010). These are both biparentally inherited nuclear markers but evolve at significantly different rates (Randi 2007). Due to the unique genealogy of each marker, any phylogeographic inference based on a single marker alone may not reflect the true evolutionary history of the species (Godinho et al. 2008; Fulton \& Strobeck 2010; Rodríguez et al. 2010; Mao et al. 2013). It is only by combining diverse markers, with varying evolutionary rates and modes of inheritance, that a more complete picture of a taxon's phylogeographic history can be achieved that encompasses different timescales (Flanders et al. 2009; Puechmaille et al. 2011). Also important for robust inference of historical phylogeographic events is adequate sampling, which ideally should mirror the species' range as far as possible to avoid overlooking localities that could harbour genetic diversity. Therefore, to reconstruct the true evolutionary history of a species, both a multimarker data set and adequate sampling in the geographic area of interest are required.

Here, we present a detailed phylogeographic study of $R$. hipposideros based on three independent marker data sets chosen for their diverse paths of inheritance and range of mutation rates (mtDNA, a nuclear intron and microsatellites) across its Western Palaearctic distribution. We compare and contrast the different inferences from each marker and hypothesise that $R$. hipposideros should show similar demographic history to $R$. ferrumequinum given their presumed similar ecological requirements. We therefore predict that $R$. hipposideros survived the ice age in one or more Mediterranean refugia, in addition to refugia in the Middle East, and that loss of genetic diversity during recolonization will have led to reduced diversity at the northwest limit of the colonization front. Through the use of diverse molecular markers, we also elucidate past demographic events, which occurred before and after the formation of glacial refugia during the Quaternary ice ages.

\section{Materials and methods}

\section{Sampling and DNA extraction}

Tissue samples or extracted DNA of R. hipposideros were collected from 86 localities across the species' range (Table 1; Fig. 1). Tissue samples were typically 3$\mathrm{mm}$ biopsies of the wing membrane taken using a sterile biopsy punch (Stiefel Laboratories, Offenbach Germany). Samples were stored at $-20^{\circ}$ in $100 \%$ ethanol or desiccated in silica gel (Sorbead orange Chameleon, Hannover Germany). Additionally, we also included samples of DNA extracted from $R$. hipposideros faeces collected in Brittany, France, using noninvasive sampling techniques (Puechmaille \& Petit 2007; Puechmaille et al. 2007) that have been shown to provide results similar to tissue samples (Boston et al. 2012). Whole genomic DNA was extracted using either a modified salt-chloroform extraction as described in Puechmaille et al. (2011) or a Promega Genomic DNA purification system (Promega, WI, USA). Extracted samples were quantified on a NanoDrop ${ }^{\circledR}$ ND-1000 Spectrophotometer (Thermo Fisher Scientific).

\section{Nuclear intron amplification and analysis}

Intron 4 of the biglycan gene (Bgn) was amplified for a geographically representative subset of samples $(n=125)$. A subset was used due to the expected low molecular diversity of this intron. The 600-bp fragment was amplified using primers published by Lyons et al. (1997). PCRs were carried out in $25 \mu \mathrm{L}$ reaction volumes containing $2 \mu \mathrm{L}$ of DNA (10 ng/ $\mu \mathrm{L}), 1 X$ PCR buffer without $\mathrm{Mg}$ (Invitrogen, $\mathrm{CA}$, USA), $1.5 \mathrm{~mm} \mathrm{MgCl}_{2}$, $0.4 \mu \mathrm{M}$ each primer, $0.2 \mathrm{~mm}$ dNTPs and $1 \mathrm{U}$ Platinum Taq DNA Polymerase High Fidelity (Invitrogen, CA, USA). PCRs were carried out on a T3000 Thermocycler (Biometra, Göttingen, Germany) under the following conditions: $95{ }^{\circ} \mathrm{C}$ for $10 \mathrm{~min} ; 2$ cycles of $95{ }^{\circ} \mathrm{C}$ for $15 \mathrm{~s}$, $65{ }^{\circ} \mathrm{C}$ for $30 \mathrm{~s}, 72{ }^{\circ} \mathrm{C}$ for $1 \mathrm{~min}$; followed by 2 cycles each at annealing temperature in $2{ }^{\circ} \mathrm{C}$ decrements from $65{ }^{\circ} \mathrm{C}\left(63^{\circ} \mathrm{C}-55^{\circ} \mathrm{C}\right) ; 72{ }^{\circ} \mathrm{C}$ for $5 \mathrm{~min}$. PCR products were purified using Exo-SAP (Roche, Basel, Switzerland), following the manufacturer's protocol. Amplicons were sequenced using Sanger sequencing by Macrogen Inc. (Seoul, Korea). Sequences were edited using Sequencher v.4.7 (Gene Codes Corp. MI, USA) and aligned manually using Se-Al 2.0 (Rambaut 1996) with 
Table 1 Sampling details for R. hipposideros showing the numbers of individuals typed at each of the molecular markers. Sampling sites are marked in Fig. 1. Suppliers of samples are denoted by their initials: SD, S. Dool; GJ, G. Jones; EP, E. Petit; SJP, S. J. Puechmaille; FC, F. Catzeflis; SR, S. Roué; EC, E. Cosson; SJR, S. J. Rossiter; JJ, J. Juste; CI, C. Ibáñez, CD, C. Dietz; AM, Adriano Martinoli; RT, Roberto Toffoli; AV, Andrea Viglino; DR, Danilo Russo; PH, P. Hulva; MJ, Maria Jerabek, VM, Vitaliy Matveev

\begin{tabular}{|c|c|c|c|c|c|c|c|}
\hline Site & Origin & Easting & Northing & mtDNA & Intron & Microsatellite & Supplier \\
\hline 1 & Ireland, Mayo & $-09^{\circ} 19^{\prime}$ & $53^{\circ} 32^{\prime}$ & 4 & 2 & 10 & SD \\
\hline 2 & Ireland, Galway & $-08^{\circ} 52^{\prime}$ & $53^{\circ} 04^{\prime}$ & 5 & 4 & - & SD \\
\hline 3 & Ireland, Clare & $-08^{\circ} 59^{\prime}$ & $52^{\circ} 55^{\prime}$ & 5 & 2 & - & $\mathrm{SD}$ \\
\hline 4 & Ireland, Limerick & $-08^{\circ} 51^{\prime}$ & $52^{\circ} 35^{\prime}$ & 4 & 6 & - & SD \\
\hline 5 & Ireland, Kerry & $-09^{\circ} 39^{\prime}$ & $51^{\circ} 52^{\prime}$ & 26 & 4 & - & $\mathrm{SD}$ \\
\hline 6 & Ireland, Kerry & $-09^{\circ} 51^{\prime}$ & $51^{\circ} 59^{\prime}$ & 23 & 2 & - & SD \\
\hline 7 & Ireland, Cork & $-09^{\circ} 05^{\prime}$ & $51^{\circ} 51^{\prime}$ & 9 & 5 & 27 & $\mathrm{SD}$ \\
\hline 8 & Britain, England & $-02^{\circ} 56^{\prime}$ & $51^{\circ} 03^{\prime}$ & 9 & 3 & 8 & GJ \\
\hline 9 & Britain, Wales & $-03^{\circ} 23^{\prime}$ & $51^{\circ} 56^{\prime}$ & 36 & 3 & 25 & GJ \\
\hline 10 & France, St-Thurial & $-01^{\circ} 55^{\prime}$ & $48^{\circ} 01^{\prime}$ & 5 & - & - & $\mathrm{EP}$ \\
\hline 11 & France, Pluherlin & $-02^{\circ} 21^{\prime}$ & $47^{\circ} 41^{\prime}$ & 6 & - & - & $\mathrm{EP}$ \\
\hline 12 & France, Epiniac & $-01^{\circ} 44^{\prime}$ & $48^{\circ} 30^{\prime}$ & 6 & - & - & $\mathrm{EP}$ \\
\hline 13 & France, Paimpont & $-02^{\circ} 13^{\prime}$ & $48^{\circ} 00^{\prime}$ & 1 & 1 & - & SJP \\
\hline 14 & France, Verneuil & $03^{\circ} 15^{\prime}$ & $46^{\circ} 20^{\prime}$ & 1 & 1 & - & $\mathrm{FC}$ \\
\hline 15 & France, St-Brisson & $04^{\circ} 10^{\prime}$ & $47^{\circ} 15^{\prime}$ & 5 & 1 & 12 & SR \\
\hline 16 & France, Graissac & $02^{\circ} 48^{\prime}$ & $44^{\circ} 47^{\prime}$ & 2 & 1 & - & SJP \\
\hline 17 & France, Lagarde & $02^{\circ} 09^{\prime}$ & $44^{\circ} 25^{\prime}$ & 13 & - & - & SJP \\
\hline 18 & France, Motclus & $04^{\circ} 25^{\prime}$ & $44^{\circ} 15^{\prime}$ & 6 & - & - & SJP \\
\hline 19 & France, Mormoiron & $05^{\circ} 11^{\prime}$ & $44^{\circ} 04^{\prime}$ & 1 & - & - & SJP \\
\hline 20 & France, Vacheres & $05^{\circ} 38^{\prime}$ & $43^{\circ} 55^{\prime}$ & 2 & - & - & $\mathrm{EC}$ \\
\hline 21 & France, Lantosque & $07^{\circ} 18^{\prime}$ & $43^{\circ} 58^{\prime}$ & 1 & - & - & SJP \\
\hline 22 & Spain, Galicia & $-08^{\circ} 07^{\prime}$ & $42^{\circ} 34^{\prime}$ & 2 & 2 & - & SJR \\
\hline 23 & Spain, La Rioja & $-02^{\circ} 52^{\prime}$ & $42^{\circ} 13^{\prime}$ & 9 & 2 & 7 & $\mathrm{JJ} / \mathrm{CI}$ \\
\hline 24 & Spain, Girona & $02^{\circ} 37^{\prime}$ & $42^{\circ} 20^{\prime}$ & 3 & 1 & - & $\mathrm{JJ} / \mathrm{CI}$ \\
\hline 25 & Spain, Malaga & $-04^{\circ} 05^{\prime}$ & $36^{\circ} 45^{\prime}$ & 20 & 3 & 3 & $\mathrm{JJ} / \mathrm{CI}$ \\
\hline 26 & Spain, Granada & $-03^{\circ} 53^{\prime}$ & $36^{\circ} 59^{\prime}$ & 9 & 3 & 4 & $\mathrm{JJ} / \mathrm{CI}$ \\
\hline 27 & Ceuta, Fuerte Isabel II & $-05^{\circ} 21^{\prime}$ & $35^{\circ} 53^{\prime}$ & 11 & 2 & 7 & $\mathrm{JJ} / \mathrm{CI}$ \\
\hline 28 & Morocco, Tetuan & $-05^{\circ} 19^{\prime}$ & $35^{\circ} 10^{\prime}$ & 1 & - & - & $\mathrm{JJ} / \mathrm{CI}$ \\
\hline 29 & Morocco, Azrou & $-05^{\circ} 24^{\prime}$ & $33^{\circ} 04^{\prime}$ & 1 & 1 & - & $\mathrm{JJ} / \mathrm{CI}$ \\
\hline 30 & Morocco, Tazouguerte & $-03^{\circ} 47^{\prime}$ & $32^{\circ} 04^{\prime}$ & - & 1 & - & $\mathrm{JJ} / \mathrm{CI}$ \\
\hline 31 & Sardinia, G. di M. Majore & $08^{\circ} 42^{\prime}$ & $40^{\circ} 31^{\prime}$ & 1 & 1 & - & $\mathrm{CD}$ \\
\hline 32 & Italy, Lasa, Bremsberg & $10^{\circ} 41^{\prime}$ & $46^{\circ} 36^{\prime}$ & 4 & 4 & - & $\mathrm{AM}$ \\
\hline 33 & Italy, Andrate & $07^{\circ} 52^{\prime}$ & $45^{\circ} 33^{\prime}$ & 1 & 1 & - & RT \\
\hline 34 & Italy, Cuneo & $07^{\circ} 23^{\prime}$ & $44^{\circ} 15^{\prime}$ & 1 & 1 & - & RT \\
\hline 35 & Italy, Liguria & $07^{\circ} 32^{\prime}$ & $43^{\circ} 52^{\prime}$ & 3 & - & - & RT \\
\hline 36 & Italy, Tuscany, Prato & $11^{\circ} 07^{\prime}$ & $43^{\circ} 58^{\prime}$ & 1 & - & - & $\mathrm{AV}^{*}$ \\
\hline 37 & Italy, Tuscany, Siena & $11^{\circ} 12^{\prime}$ & $43^{\circ} 22^{\prime}$ & 1 & - & - & $\mathrm{AV}^{* *}$ \\
\hline 38 & Italy, Villetta Barrea & $13^{\circ} 56^{\prime}$ & $41^{\circ} 46^{\prime}$ & 1 & 1 & - & $\mathrm{DR}$ \\
\hline 39 & Italy, Castellammare di Stabia & $14^{\circ} 29^{\prime}$ & $40^{\circ} 41^{\prime}$ & 1 & 1 & - & DR \\
\hline 40 & Italy, Sorrento & $14^{\circ} 22^{\prime}$ & $40^{\circ} 37^{\prime}$ & 3 & 3 & - & DR \\
\hline 41 & Malta, Gozo, Calypso cave & $14^{\circ} 16^{\prime}$ & $36^{\circ} 03^{\prime}$ & 1 & 1 & - & $\mathrm{PH}$ \\
\hline 42 & Malta, Gozo, Ghajn Abdul & $14^{\circ} 12^{\prime}$ & $36^{\circ} 02^{\prime}$ & 2 & 2 & - & $\mathrm{PH}$ \\
\hline 43 & Tunisia, Hotel des chênes & $08^{\circ} 40^{\prime}$ & $36^{\circ} 44^{\prime}$ & 7 & 6 & - & SJP $* * * *$ \\
\hline 44 & Austria, Taxenbach & $12^{\circ} 57^{\prime}$ & $47^{\circ} 17^{\prime}$ & 4 & - & - & MJ \\
\hline 45 & Austria, Kleinarl & $13^{\circ} 19^{\prime}$ & $47^{\circ} 16^{\prime}$ & 1 & - & - & $\mathrm{CD}$ \\
\hline 46 & Austria, Wald im Pinzgau & $12^{\circ} 13^{\prime}$ & $47^{\circ} 16^{\prime}$ & 5 & 2 & - & $\mathrm{CD}$ \\
\hline 47 & Austria, Badgastein & $13^{\circ} 08^{\prime}$ & $47^{\circ} 07^{\prime}$ & 1 & - & - & $\mathrm{CD}$ \\
\hline 48 & Slovenia, Crua & $14^{\circ} 50^{\prime}$ & $46^{\circ} 27^{\prime}$ & 3 & 1 & 13 & $\mathrm{CD}$ \\
\hline 49 & Slovenia, Svetih Trije Kralji & $15^{\circ} 11^{\prime}$ & $46^{\circ} 38^{\prime}$ & 2 & 2 & 22 & $\mathrm{CD}$ \\
\hline 50 & Czech Rep., Morina & $14^{\circ} 11^{\prime}$ & $50^{\circ} 00^{\prime}$ & 1 & 1 & - & $\mathrm{PH}$ \\
\hline 51 & Slovakia, Silica & $20^{\circ} 31^{\prime}$ & $48^{\circ} 33^{\prime}$ & 1 & 1 & - & $\mathrm{PH}$ \\
\hline 52 & Slovakia, Hodrus-Hamre & $18^{\circ} 44^{\prime}$ & $48^{\circ} 27^{\prime}$ & 1 & - & - & $\mathrm{PH}$ \\
\hline 53 & Slovakia, Zlatno & $19^{\circ} 49^{\prime}$ & $48^{\circ} 31^{\prime}$ & 1 & - & - & $\mathrm{PH}$ \\
\hline
\end{tabular}


Table 1 Continued

\begin{tabular}{|c|c|c|c|c|c|c|c|}
\hline Site & Origin & Easting & Northing & mtDNA & Intron & Microsatellite & Supplier \\
\hline 54 & Slovakia, Licince & $20^{\circ} 17^{\prime}$ & $48^{\circ} 32^{\prime}$ & 1 & - & - & $\mathrm{PH}$ \\
\hline 55 & Kosovo, Bubel & $20^{\circ} 39^{\prime}$ & $42^{\circ} 31^{\prime}$ & 1 & 1 & - & $\mathrm{PH}$ \\
\hline 56 & Bulgaria, Muselievo & $24^{\circ} 51^{\prime}$ & $43^{\circ} 37^{\prime}$ & 7 & - & - & $\mathrm{CD}$ \\
\hline 57 & Bulgaria, Muselievo & $24^{\circ} 51^{\prime}$ & $43^{\circ} 36^{\prime}$ & 5 & - & - & $\mathrm{CD}$ \\
\hline 58 & Bulgaria, Schernov & $24^{\circ} 51^{\prime}$ & $43^{\circ} 40^{\prime}$ & 4 & - & - & CD \\
\hline 59 & Bulgaria, Parnitzite & $24^{\circ} 25^{\prime}$ & $43^{\circ} 12^{\prime}$ & 3 & - & - & CD \\
\hline 60 & Bulgaria, Devetaki & $24^{\circ} 52^{\prime}$ & $43^{\circ} 13^{\prime}$ & 2 & - & - & $\mathrm{CD}$ \\
\hline 61 & Bulgaria, Vetovo/Razgrad & $26^{\circ} 20^{\prime}$ & $43^{\circ} 38^{\prime}$ & 5 & 5 & - & SJP \\
\hline 62 & Bulgaria, central Balkans & $25^{\circ} 13^{\prime}$ & $42^{\circ} 46^{\prime}$ & 21 & 9 & - & SJP \\
\hline 63 & Greece, Mikrolimni & $21^{\circ} 60^{\prime}$ & $40^{\circ} 44^{\prime}$ & 4 & 4 & - & SJP \\
\hline 64 & Greece, Kombotades & $22^{\circ} 20^{\prime}$ & $38^{\circ} 52^{\prime}$ & 2 & 2 & - & $\mathrm{PH}$ \\
\hline 65 & Crete, Gerani & $23^{\circ} 54^{\prime}$ & $35^{\circ} 31^{\prime}$ & 2 & 1 & - & $\mathrm{PH}$ \\
\hline 66 & Crete, Milatos & $25^{\circ} 34^{\prime}$ & $35^{\circ} 18^{\prime}$ & 2 & 2 & - & $\mathrm{PH}$ \\
\hline 67 & Turkey, Gündogan & $27^{\circ} 20^{\prime}$ & $37^{\circ} 07^{\prime}$ & 1 & 2 & - & $\mathrm{CD}$ \\
\hline 68 & Turkey, exact locality unknown & - & - & 2 & 2 & - & $\mathrm{PH}$ \\
\hline 69 & Cyprus, Sylyllos & $32^{\circ} 59^{\prime}$ & $35^{\circ} 00^{\prime}$ & - & 1 & - & $\mathrm{CD}$ \\
\hline 70 & Cyprus, Cinarli/Platani & $33^{\circ} 45^{\prime}$ & $35^{\circ} 19^{\prime}$ & 4 & 2 & 5 & $\mathrm{PH}$ \\
\hline 71 & Cyprus, Troodos forest & $32^{\circ} 53^{\prime}$ & $34^{\circ} 57^{\prime}$ & 10 & 3 & 8 & $\mathrm{PH}$ \\
\hline 72 & Cyprus, Akamas Peninsula & $32^{\circ} 18^{\prime}$ & $35^{\circ} 03^{\prime}$ & 6 & 1 & 4 & $\mathrm{PH}$ \\
\hline 73 & Lebanon, Faraiya & $35^{\circ} 49^{\prime}$ & $34^{\circ} 00^{\prime}$ & 1 & - & 1 & $\mathrm{PH}$ \\
\hline 74 & Lebanon, Port al Khalars & $35^{\circ} 53^{\prime}$ & $34^{\circ} 26^{\prime}$ & 1 & - & 1 & $\mathrm{PH}$ \\
\hline 75 & Lebanon, Haqel el Azime & $35^{\circ} 44^{\prime}$ & $34^{\circ} 10^{\prime}$ & 1 & - & 1 & $\mathrm{PH}$ \\
\hline 76 & Lebanon, Antelias & $35^{\circ} 35^{\prime}$ & $33^{\circ} 55^{\prime}$ & 1 & - & 1 & $\mathrm{PH}$ \\
\hline 77 & Lebanon, Aaqura & $35^{\circ} 54^{\prime}$ & $34^{\circ} 07^{\prime}$ & 1 & - & 1 & $\mathrm{PH}$ \\
\hline 78 & Lebanon, Bcharre & $36^{\circ} 00^{\prime}$ & $34^{\circ} 15^{\prime}$ & 1 & - & 1 & $\mathrm{PH}$ \\
\hline 79 & Lebanon, Grotto Mab'aj & $35^{\circ} 41^{\prime}$ & $33^{\circ} 51^{\prime}$ & 1 & - & 1 & $\mathrm{PH}$ \\
\hline 80 & Lebanon, Nabaa es Safa & $35^{\circ} 41^{\prime}$ & $33^{\circ} 45^{\prime}$ & 1 & - & 1 & $\mathrm{PH}$ \\
\hline 81 & Lebanon, Mrouj & $35^{\circ} 45^{\prime}$ & $33^{\circ} 54^{\prime}$ & 1 & 1 & 1 & $\mathrm{PH}$ \\
\hline 82 & Syria, Crac des Chevaliers & $36^{\circ} 17^{\prime}$ & $34^{\circ} 45^{\prime}$ & 2 & 3 & - & $\mathrm{PH}$ \\
\hline 83 & Israel, Galilea & $35^{\circ} 40^{\prime}$ & $32^{\circ} 41^{\prime}$ & 5 & 2 & - & CD \\
\hline 84 & Egypt, Wadi Shiekh Awad & $33^{\circ} 53^{\prime}$ & $28^{\circ} 39^{\prime}$ & - & 2 & - & $\mathrm{CD}$ \\
\hline 85 & Iran, Emam Sadeh & $51^{\circ} 37^{\prime}$ & $35^{\circ} 49^{\prime}$ & - & 4 & - & $\mathrm{PH}$ \\
\hline \multirow[t]{2}{*}{86} & Tajikistan, Sogdiyskaya Oblast & $69^{\circ} 40^{\prime}$ & $40^{\circ} 18^{\prime}$ & 2 & - & - & $\mathrm{VM}$ \\
\hline & Total & & & 373 & 125 & 164 & \\
\hline
\end{tabular}

*Natural History Museum of Florence cat. no. 21416, ${ }^{* *}$ Natural History Museum of Florence cat. no. 12641, ***Data on individuals published in Puechmaille et al. (2012b).

a resulting alignment length of $543 \mathrm{bp}$. As Bgn is located on the X-chromosome, the data set was analysed in PHASE 2.1 (Stephens \& Donnelly 2003) to reconstruct unknown haplotypes (females heterozygous at more than one site) from known haplotypes (males and homozygous females). Standard molecular diversity statistics were calculated in ARLEQUIN 3.5.1.3 (Excoffier \& Lischer 2010). Haplotype data were used to construct a median-joining network using NETWORK 4.6.1.1 (Bandelt et al. 1999) to illustrate graphically the relationships among the haplotypes.

\section{mtDNA amplification}

Two primer pairs were used to amplify overlapping PCR products, which together constituted the entire cytochrome b, tRNAs (threonine, proline) and partial control region. PCR amplifications, sequencing and alignment were carried out as described above for Bgn, using the primer pairs mtDNA-R3-F/mtDNA-F3-R and mtDNA-R2-F/mtDNA-F2-R (Puechmaille et al. 2011), resulting in an alignment length of $1630 \mathrm{bp}$ for all samples (Fig. S1, Supporting Information).

\section{mtDNA analysis}

Standard molecular diversity statistics were calculated in ARLEQUIN. Diversity measures were also reported for geographic groupings based on highly supported clades from the mtDNA Bayesian analysis. Sequences were collapsed into haplotypes using FaBox (Villesen 2007), and a median-joining (MJ) haplotype network was constructed in NETWORK. Phylogenetic reconstructions were performed using Bayesian inference in BEAST v1.7.4 
(Drummond \& Rambaut 2007). The TrN+G+I substitution model was used as determined by jMODELTEST 2.1.1 (Guindon \& Gascuel 2003; Darriba et al. 2012). Three species of Rhinolophidae were specified as outgroups (R. formosae, R. monoceros, R. pumilus; GenBank Accession nos: EU166918, NC_005433, AB061526). The constant population size coalescent was used as a tree prior as it was estimated to be the most likely prior for our data following comparisons of likelihood scores of multiple MCMC runs with all alternative tree priors. Three independent runs of 10 million generations sampled every 1000 were combined in TRACER v1.5 (Rambaut \& Drummond 2007) to confirm convergence on the same posterior distribution in the MCMC runs. The first 1 million runs (10\%) were discarded as burn-in.

To assess the mutation rate, we annotated and identified the start and stop positions of the tRNAs, cytb, control region ETAS and central domain using: the online published $R$. hipposideros sequences of cytb (DQ297586.1), ARWEN v.1.2 (Laslett \& Canback 2008) to identify the tRNAs and a multispecies alignment of the mammalian control region mtDNA (Sbisà et al. 1997) to annotate the partial control region. Rates of mutation for all of the defined regions have not been published for any bat species to date; therefore, we used the mutation rate estimated from the most phylogenetically close published sequences for this region (Orders Perissodactyla and Carnivora; Meredith et al. 2011; Pesole et al. 1999). The overall substitution rate for the entire fragment was estimated by combining the substitution rates contributed by the functional regions relative to their lengths (cytb length $1108 \mathrm{bp}$, substitution rate 19.7; tRNA 138 bp, substitution rate 3.2; control region HV1 $351 \mathrm{bp}$, substitution rate 20.3; control region central domain $33 \mathrm{bp}$, substitution rate 4.25; substitution rates expressed as $10^{-9} \mathrm{subs} / \mathrm{site} /$ year). The estimated substitution rate was $1.8 \%$ per site per million years with $1.4 \%$ as the lower bound and $2.1 \%$ as the upper. This rate was used to establish approximate dates for the most recent common ancestor of major clades in the phylogenetic gene tree for this species and to estimate times of population expansions.
Genetic distances between supported clades in the mtDNA analysis were calculated in MEGA v 5.1 (Tamura et al. 2011). Estimates of standard error were obtained by a bootstrap procedure (1000 replicates). Analyses were conducted using the Tamura-Nei model with rate variation among sites modelled with a gamma distribution (shape parameter $=0.803$ ). All positions containing gaps and missing data were eliminated prior to analysis. Pairwise $\Phi$ st values between supported clades were calculated and tested in ARLEQUIN (10 000 replicates).

Isolation by distance was calculated between populations across the entire data set (min. 5 individuals per population) and also within well-supported clades corresponding to sets of populations reported from the phylogenetic analysis. When our sampling was geographically sparse, we pooled individuals within a $200 \mathrm{~km}$ radius, which was shown to be the distance at which all mitochondrial haplotypes were shared or highly similar within clades. $\mathrm{F}_{\mathrm{ST}}$ among populations (Slatkin's linearized $\mathrm{F}_{\mathrm{ST}}$ ) was calculated and tested in ARLEQUIN (1000 permutations), and the distance matrix was calculated using Geographic Distance Matrix Generator v 1.2.3 (American Museum of Natural History 2010). Significance between Euclidian geographic distance and genetic distance matrices was assessed using a Mantel test (99999 permutations) implemented in the ecodist package (Goslee \& Urban 2007) in R v 2.15.2 ( $R$ Development Core Team 2012). Demographic and/or spatial population expansion events were investigated using the mismatch distribution implemented in ARLEQUIN for clades, which were defined in the Bayesian phylogenetic analysis. Time of expansion in generations $(t)$ was estimated from $\tau=2 u$ t (Rogers \& Harpending 1992) using the Mismatch Calculator (Schenekar \& Weiss 2011). The generation time for $R$. hipposideros was estimated to be 2 years on average with a range of 1 3 years (Gaisler 1966).

\section{Microsatellite amplification and analysis}

All eight microsatellite loci (Table 2) used in this study were previously developed for this species (Puechmaille

Table 2 Microsatellite multiplex primer concentrations and annealing temperatures

\begin{tabular}{lllll}
\hline Locus & Primer $(\mu \mathrm{M})$ & Multiplex & Temperature ${ }^{\circ}(\mathrm{C})$ & Reference \\
\hline RHA101 & 0.21 & 1 & 58 & Struebig et al. (2011) \\
RHA8 & 0.14 & 1 & 58 & Struebig et al. (2011) \\
RHA107 & 0.5 & 2 & 56 & Struebig et al. (2011) \\
RHA109 & 0.21 & 2 & 56 & This study \\
RHA7 & 0.37 & 2 & 56 & Struebig et al. (2011) \\
RHD103 & 0.14 & 3 & 56 & Puechmaille et al. (2005) \\
RHD102 & 0.43 & 3 & 56 & Puechmaille et al. (2005) \\
RHA105 & 0.43 & 3 & 56 & Struebig et al. (2011) \\
\hline
\end{tabular}


et al. 2005; Struebig et al. 2011) with one locus previously unpublished (Rha109 F: HEX-AGT GGG ACT AAG CCT AAC TGA G and R: GTT TAC GGT GGG ACA TAA GTA AGA AT; GenBank Accession no: KC978717). Three multiplex PCRs were performed for all individuals. Each reaction consisted of $1 \mu \mathrm{L}$ DNA extract $(10 \mathrm{ng} / \mu \mathrm{L}), 1 \times$ Multiplex PCR Master Mix (QIAGEN, Hilden, Germany), primer concentrations as reported in Table 2 and total reaction volumes of $7 \mu \mathrm{L}$. Amplification conditions were as described in Puechmaille et al. (2005) multiplex amplification. PCRs were carried out on a DNA Engine TETRAD thermocycler (MJ Research, MA, USA). All PCR products were run on an ABI PRISM 3730XL Genetic Analyser (Applied Biosystems, CA, USA) and sized with an internal lane standard (400HD ROX) and the software GENEMAPPER v. 4.0 (Applied Biosystems).

Departures from Hardy-Weinberg and linkage equilibrium were tested in FSTAT v. 2.9.3.2 (Goudet 2001) at the colony level. LositAN v.1.0.0 (Beaumont \& Nichols 1996; Antao et al. 2008) was used to test for markers under selection. MICRO-CHECKER (Van Oosterhout et al. 2004) was used to check for the presence of null alleles, large allele dropout and possible scoring errors. Genetic diversity indices $\mathrm{F}_{\mathrm{IS}}$ (inbreeding coefficient) and allelic richness $(R)$ were estimated in FSTAT. Average expected and observed heterozygosity $\left(\mathrm{H}_{\mathrm{E}}\right.$ and $\left.\mathrm{H}_{\mathrm{O}}\right)$ were calculated in ARLEQUIN. Estimates of population differentiation were inferred using $F_{\mathrm{ST}}$ in FSTAT and $\mathrm{D}_{\text {est }}$ (Jost 2008) in SMOGD v.1.2.5 (Crawford 2009). Population structure was examined using PCA in the adegenet (v. 1.3-5) and ade4 (v. 1.5-1) packages in R (Dray \& Dufour 2007; Jombart 2008) based on centred allele frequencies at the population level. BARRIER v. 2.2 (Manni et al. 2004) was used to test for zones of abrupt change in the pattern of genetic variation between populations (1000 bootstrap matrices).

\section{Results}

Nuclear intron: genetic diversity and phylogenetic structure

There were 22 haplotypes among the 125 samples used in the nuclear intron study (GenBank Accessions KC978153-KC978343) with a maximum difference of seven base pairs between the most divergent haplotypes. Haplotype and nucleotide diversity levels were highest in individuals from the east of the species range in Iran, Cyprus and Turkey (Table S1, Supporting Information; Fig. 2). The eastern individuals $(n=23)$ contained a total of 17 haplotypes (Fig. 3). The remainder of the samples taken from populations across Europe and north Africa all shared a haplotype that
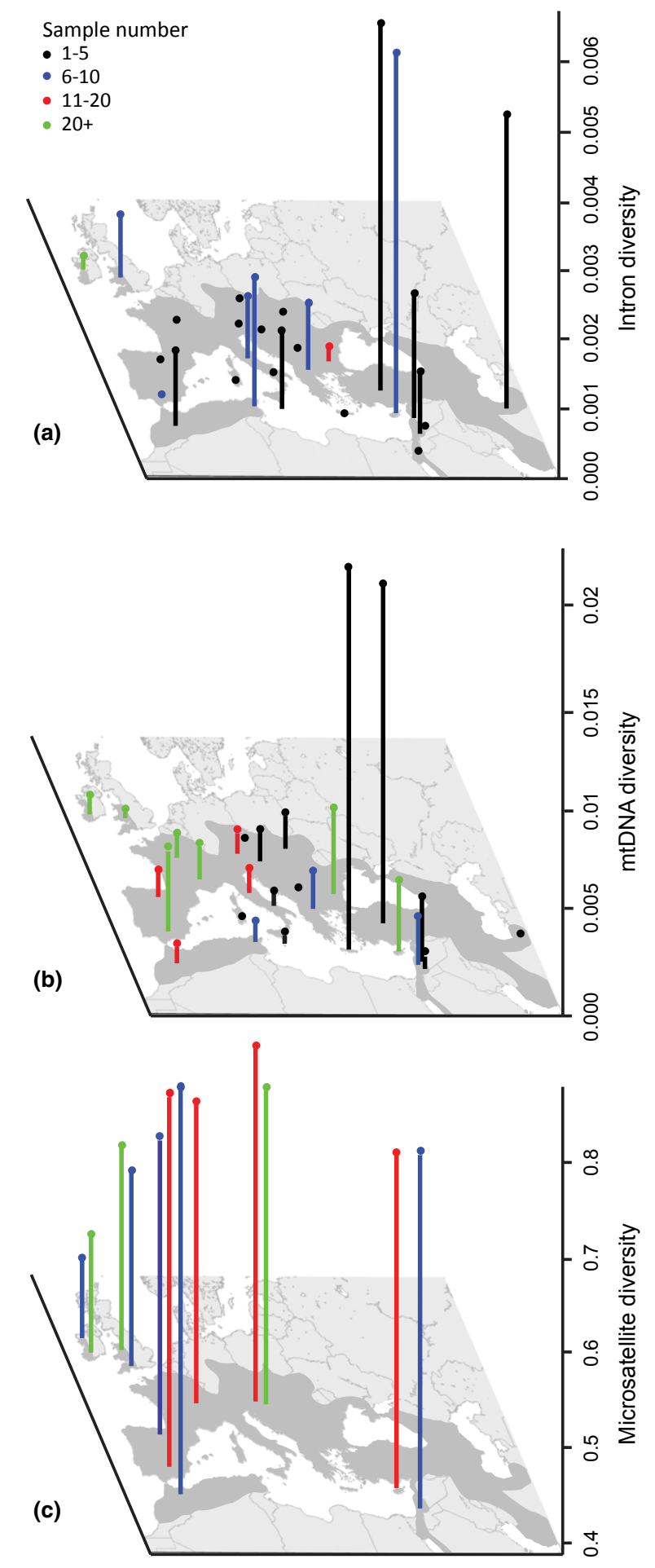

Fig. 2 Molecular diversity of $R$. hipposideros populations based on (a) nuclear intron (nucleotide diversity), (b) mtDNA (nucleotide diversity) and (c) microsatellite $\left(\mathrm{H}_{\mathrm{E}}\right)$. Each data point is coloured according to sample number.

occurs at high frequency, or a haplotype closely related to this, with two exceptions: a Slovakian bat (pale blue in the east group, Fig 3) shared a haplotype with the 


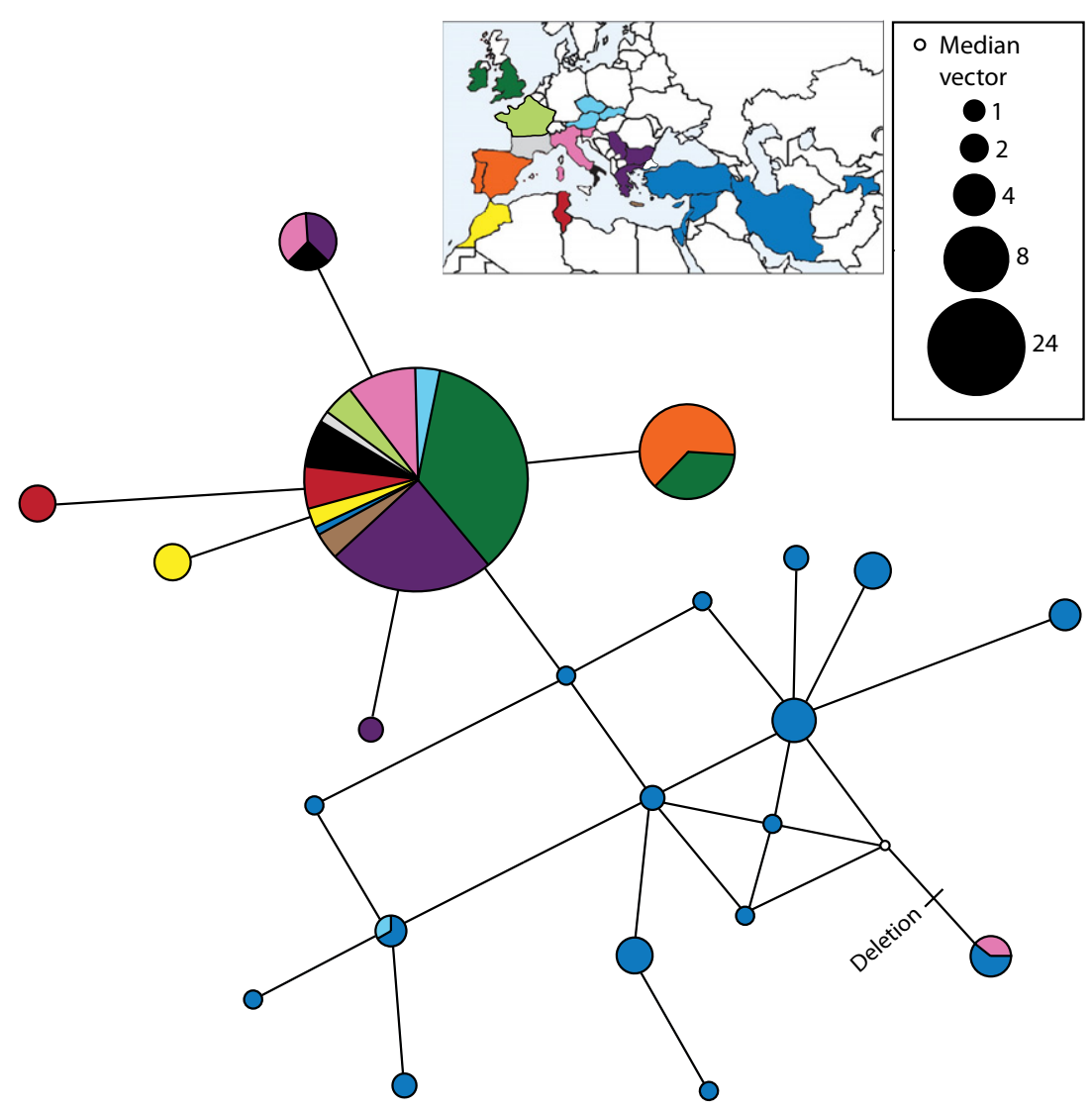

Fig. 3 MJ network for Bgn intron 4 based on a sample $(n=125)$ of geographically representative sequences from across the distribution of $R$. hipposideros. Branch lengths are proportional to base-pair changes. Sampling locations and haplotype frequency scale are shown in inset.

more easterly group and likewise a Sardinian bat (pink in the east group, Fig 3) shared a haplotype with two Egyptian bats despite the large geographic distance between these locations (Fig. 3).

\section{mtDNA: genetic diversity and phylogenetic structure}

Suspected nuclear copies of the mitochondrial genome (NUMTS) were identified $(n=5)$ at initial sequence analysis by unusually high divergence from the rest of the data set (though none with stop codons in cytb). These, with 15 randomly selected individuals, were reamplified for a larger fragment of mtDNA (primers mtDNA-R3-F/mtDNA-F2-R; 1800 bp) which amplified the correct homologous stretch of mtDNA.

A total of 135 haplotypes were found in the 373 individuals based on the 1630-bp fragment of mtDNA amplified (GenBank Accessions KC978344-KC978716). Haplotype diversity varied between localities (Table S2, Supporting Information; Fig. 2). All measures of genetic diversity were highest in the east of the species range (Turkey, Crete, Cyprus), with further diverse populations located in southern Iberia and Bulgaria. Among the least diverse populations were those from Ireland and Britain at the northwest limits of the species' range, despite having the highest levels of sampling from this region.
The Bayesian phylogenetic tree and the phylogenetic network based on mtDNA suggested high levels of geographic structuring (Fig. 4), including a large group from the east of the range ('East clade'), numerous distinct groups located across the Mediterranean and a large group comprising populations that span northwestern to central Europe ('West clade'). All supported population groups were found to be genetically distinct from each other, with divergence ranging from $1.1 \%$ up to $3.8 \%$ between clades (Table 3), and all pairwise $\Phi$ st values were significant except those between the Crete/ Balkan clades and Crete/South Italy-Malta clades (Table S3; Supporting Information). Within the genetically diverse East clade (0.99 Bayesian posterior probability: BPP; Fig. 4), populations showed further geographic structuring, dividing into a Middle East subclade (Lebanon, Syria, Turkey, Israel; $0.96 \mathrm{BPP}$ ) and a Cyprus subclade (with a single individual from Crete; $1 \mathrm{BPP}$ ). Basal to the East clade, there were individuals from Tajikistan, which were highly dissimilar to the remainder of this clade. The several Mediterranean population groups included populations from southern Iberia and Morocco ('Ibero-Maghreb clade'; 0.99 BPP), Crete, northern Iberia, Tunisia, the Balkans and southern ItalyMalta (all 1 BPP), all of which contained haplotypes unique to their region. The remainder of the network 


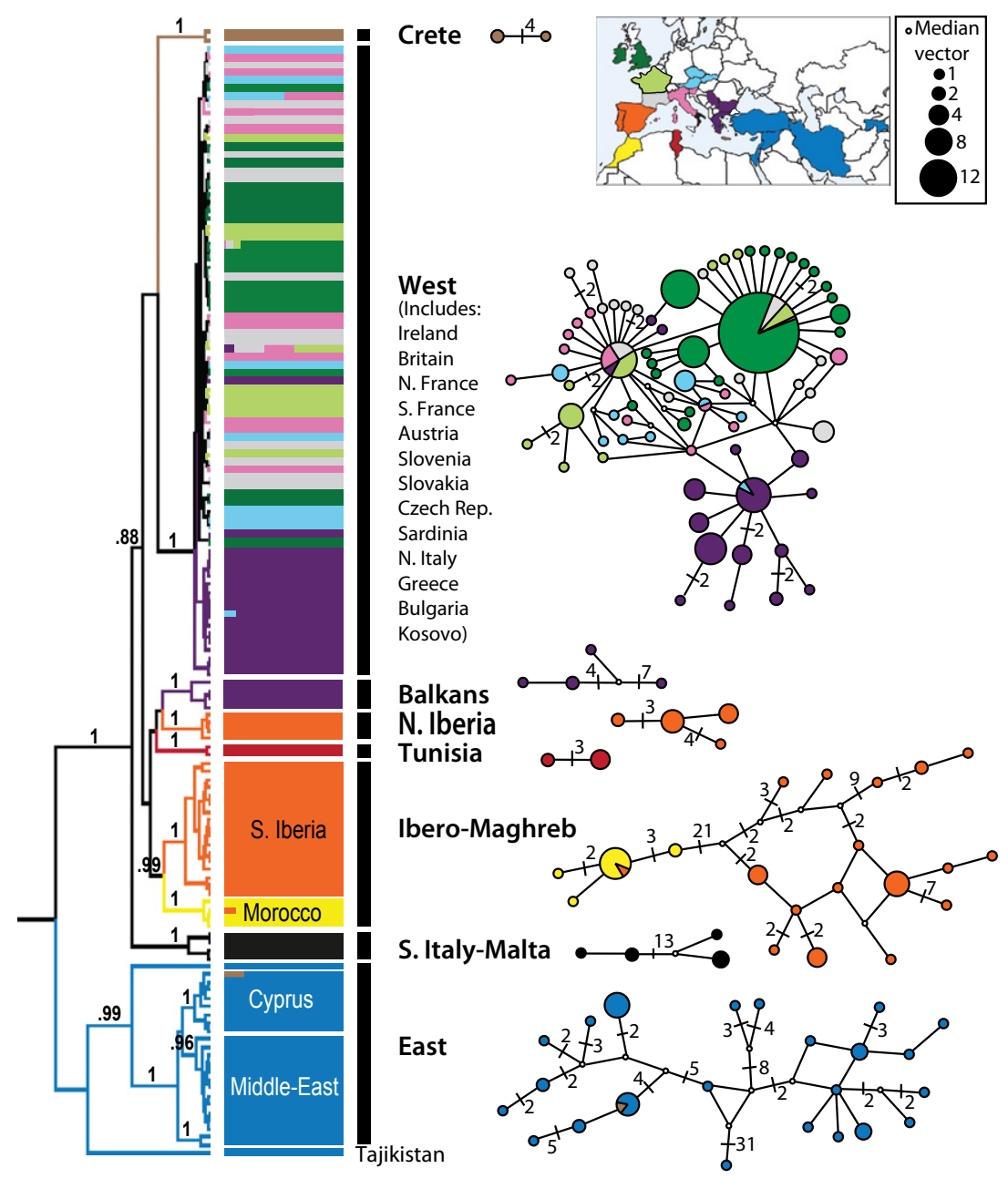

Fig. 4 Bayesian phylogenetic tree and Median-joining haplotype networks for $R$. hipposideros based on 1630bp of mtDNA (cytb, tRNA proline and threonine and partial control region). Bayesian posterior probabilities (BPP) greater than 0.85 are shown above branches. Proportional geographic origin of shared haplotypes is indicated in colour at the branch tips, and major supported clades are indicated by black bars. Median-joining haplotype networks for each clade supported in the phylogenetic analysis are shown adjacent to the corresponding clades in the tree. Sampling locations and haplotype frequency scale are shown in inset. The Bayesian phylogeny used unique haplotypes only $(n=135)$ and is shown with out-groups removed ( $R$. hipposideros formed a monophyletic group). All mtDNA sequences $(n=373)$ were used in the Median-joining networks in which branch lengths are not proportional to base-pair changes (all changes are 1 base pair unless otherwise indicated).

Table 3 Estimates of evolutionary divergence over mtDNA sequence pairs between clades within $R$. hipposideros. The number of base substitutions per site, from averaging over all sequence pairs between clades, is shown (lower diagonal) with standard error estimates shown above the diagonal

\begin{tabular}{|c|c|c|c|c|c|c|c|c|}
\hline & 1. & 2. & 3. & 4. & 5. & 6. & 7. & 8. \\
\hline 1. West & & 0.004 & 0.004 & 0.005 & 0.002 & 0.003 & 0.003 & 0.003 \\
\hline 2. Tunisia & 0.019 & & 0.005 & 0.005 & 0.003 & 0.003 & 0.004 & 0.004 \\
\hline 3. S. Italy-Malta & 0.023 & 0.029 & & 0.005 & 0.004 & 0.004 & 0.005 & 0.004 \\
\hline 4. East & 0.032 & 0.038 & 0.037 & & 0.005 & 0.005 & 0.005 & 0.005 \\
\hline 5. Balkan & 0.011 & 0.018 & 0.023 & 0.032 & & 0.003 & 0.003 & 0.003 \\
\hline 6. Ibero-Maghreb & 0.016 & 0.019 & 0.028 & 0.034 & 0.016 & & 0.003 & 0.003 \\
\hline 7. North Iberia & 0.015 & 0.020 & 0.028 & 0.036 & 0.015 & 0.016 & & 0.004 \\
\hline 8. Crete & 0.012 & 0.019 & 0.025 & 0.033 & 0.014 & 0.018 & 0.018 & \\
\hline
\end{tabular}

was composed of populations sampled from across central and western Europe excluding Iberia (the West clade; Fig. 4 \& Supporting Information, Table S2; 1 BPP). This group was characterized by few mutations between each haplotype and lacked clear geographic structuring (with the exception of a Balkan subnetwork) with haplotypes shared across the continent. Apart from the clear East vs. Europe plus Northern Africa split, the relationships between the supported European and Northern African clades remained unresolved. Estimations of the age of the most recent common ancestor of the supported groups suggested that all groups arose during the middle to late Pleistocene (Table S4 - Supporting Information). 
mtDNA: demographic analysis

Isolation by distance was demonstrated for this species across its range $\left(R^{2}=0.192, P<0.001\right)$ and among the western populations (West clade; $R^{2}=0.474$, $P<0.001$ ), but could not be estimated in additional clades due to insufficient population level sampling. Spatial and demographic models of population expansion were tested on all supported clades, as identified by the Bayesian analyses (Fig. 4). The set of western populations alone produced a smooth unimodal mismatch distribution best fitting a model of demographic expansion $\left[\mathrm{P}_{\mathrm{SSD}}=0.56, \mathrm{P}_{\mathrm{Rag}}=0.82,95 \% \mathrm{CI}\right.$ Theta $0(0$ 1.4), Theta 1 (4.57-99999)] approximately dated to 55 kyr (CI 47 502-71 253).

\section{Microsatellite data: genetic diversity and population structure}

One hundred and sixty four individuals were successfully genotyped at all eight loci. No departures from linkage and Hardy-Weinberg equilibrium were detected after Bonferroni correction, and no locus was found to be under selection. No evidence was found for the presence of null alleles, allelic dropout or scoring errors due to stutter. Measures of genetic diversity (Table S5, Supporting Information; Fig. 2) for each population were highest in populations in the east of the species range (Cyprus, Lebanon), southern Iberia, north Africa and Slovenia whilst the lowest levels of diversity were found in populations at the northwestern edge of the species range (Ireland and Britain).

The PCA results based on allelic frequencies of populations (Fig. 5) showed some congruence with patterns of mtDNA structure (Fig. 4). In particular, Spanish populations (from northern and southern Iberia) remained distinct both from each other and from all remaining populations. The first axis, which accounted for $33.9 \%$ of the total genetic variation between populations, distinguished the northwest European populations, East clade and east European populations, from the Iberian and Moroccan populations. The second axis (18\%) defined two groups: an east European (Slovenian) group and all remaining populations. The third axis $(14.5 \%)$ discriminated between the East populations (Cyprus, Lebanon) and all other populations. The main structuring on the fourth axis was between the Moroccan vs. all other populations (10.7\%). $\mathrm{F}_{\mathrm{ST}}$ between populations illustrated that whilst Ireland, Britain and France (West clade) populations are geographically closest to Iberia, the $\mathrm{F}_{\mathrm{ST}}$ values between the West clade populations and the geographically more distant East clade and east European populations are generally equal to or lower than those between the Iberian and West clade

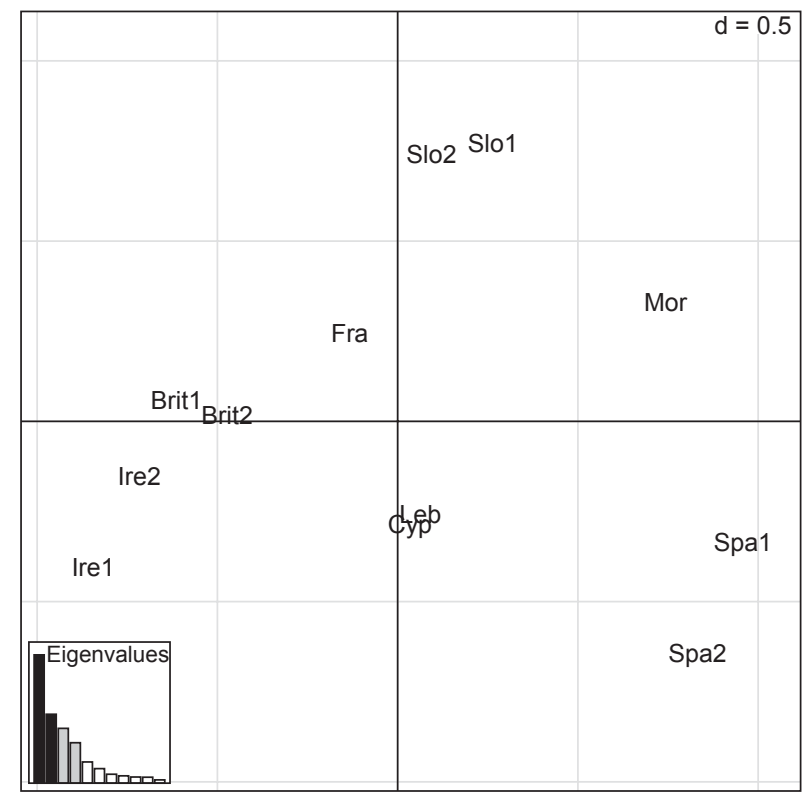

Fig. 5 Principal components analysis (PCA) of populations of $R$. hipposideros based on allelic frequencies of 8 microsatellite loci. Eigenvalues corresponding to the represented components are filled in black, with the first axis ( $X$-axis) explaining 33.9\% of the variance and the second axis ( $Y$-axis) $18.0 \%$. For population information see, Table S5, Supporting Information.

populations (Table 4). The $\mathrm{F}_{\mathrm{ST}}$ value between populations in northern Iberia and southern Iberia was low, suggesting a significant exchange of migrants between these populations. The $\mathrm{F}_{\mathrm{ST}}$ values between populations in Iberia and those from Morocco were higher, suggesting limited exchange across the Gibraltar strait for this species. Similarly, estimates of genetic differentiation based on $\mathrm{D}_{\text {est }}$ values (Table S6, Supporting Information) show that levels of differentiation between geographically close populations are low, except in the case of the Iberian and northwest European populations (Ireland, Britain, France). There was strong support for a genetic discontinuity between the two Iberian populations and other west European populations (99.7\%), decreasing to $88 \%$ between northern Iberia and France, with no subsequent barriers in our data set receiving even moderate support as estimated using BARRIER.

\section{Discussion}

Combining information from three diverse markers resulted in three distinct spatio-temporal snapshots of Rhinolophus hipposideros' demographic past. The nuclear intron data, as a consequence of its estimated low mutation rate, provide insights into the most ancient events, which occurred in this species' past. Highest diversity at this marker was found in geographic locations in the 
East (Turkey and further east). The intronic haplotype network suggests an eastern origin for the European and North African populations. An early colonization of Europe by this species agrees with fossil findings of $R$. hipposideros that have been dated from the Pliocene to the present (Storch 1974). It is noteworthy that an early colonization event from the east (a West Asian refugium) was also reported for the congeneric species, R. ferrumequinum (Flanders et al. 2009), which has similar habitat requirements.

The mitochondrial data set is informative over time frames within the last million years and reveals several well-defined geographic clades, resulting from a split in the continental populations to refugia in multiple locations across the Mediterranean: northern and southern Iberia, Morocco, Tunisia, Southern Italy and Malta, Crete, the Balkans and one or more eastern locations. The results suggest that there are two lineages present in Bulgaria; one of which most likely originated from the Balkan refugium (closest to N. Iberia in Fig. 4) and a second lineage found within the West clade. Few of the relationships between clades were supported in the Bayesian analysis; therefore, the sister clade of the West is uncertain. Within the West clade, the network indicates equally diverse populations in southern France, central-north Italy/Slovenia and Greece, possibly indicating more recent and short-lived refugia in one or more of these areas, or reduced but interconnected populations across the northern Mediterranean. The presence of two distinct clades within North Africa (in Morocco and Tunisia) has been described in other mammals (Cosson et al. 2005; Biollaz et al. 2010; Gaubert et al. 2011), and further sampling of R. hipposideros in Algeria is needed to assess possible contact between these two clades. The finding of multiple refugia in Iberia has also been described for diverse taxa (Gómez \& Lunt 2007).

The genetically diverse refugial populations present in northern Iberia and the Ibero-Maghreb clade have remained within Iberia and North Africa (despite the extensive land connection between Spain and France), as is the case for many studied European mammal species (Bilton et al. 1998; Deffontaine et al. 2005; Kotlik et al. 2006; Vega et al. 2010). One of several karyotypes within R. hipposideros has been described from Jaén, Southern Spain (Puerma et al. 2008) and the consequences of karyotypic variation within this species merit further study. It is possible that gene flow between karyotypic variants might be limited, and it would be of particular interest to study simultaneously gene flow and karyotypic variation among the same individuals from across Western Europe, including Iberia. The Pyrenees may act as a barrier to gene flow or to recolonization in some species, and this idea is 
substantiated by the mtDNA and microsatellite data. No Iberian haplotypes (mtDNA) were found in the remainder of Europe (West clade), and microsatellite loci supported a substantial level of population differentiation between Iberian vs. western European populations. Further population level genetic sampling of this species at proposed contact zones between refugial clades is necessary to fully assess whether there is secondary contact and/or gene flow between clades.

The Pyrenees and Alps, as well as water bodies, have all been shown to act as barriers of varying importance to the movement of several different bat species studied to date. For example, in some cases they act as impermeable barriers for highly vagile/migratory species (Castella et al. 2000; Ruedi et al. 2008), and in other cases, allow for high levels of gene flow for sedentary species (Garcia-Mudarra et al. 2009). Myotis myotis (greater mouse-eared bat) can disperse over several hundreds of kilometres, but diverse lineages which occurred in the Italian peninsula during the quaternary glaciations have remained there (Ruedi et al. 2008). Plecotus auritus (brown long-eared bat) utilized glacial refugia in Iberia and the Balkans, with lineages recolonizing from both refugia and coming into secondary contact in central Europe (Juste et al. 2004). R. ferrumequinum used at least two Mediterranean refugia (Iberia and/or Italy in addition to Balkans/Greece) and recolonized from both. Therefore, it is of utmost importance to ascertain the demographic history of individual species in Europe as it is not possible to predict species-specific barriers to gene flow, even when comparing closely related species.

At the mtDNA level, a northern cline in genetic diversity exists in Europe following the path of colonization from southern refugia (with the highest levels of diversity) to Ireland in the northwest (with the lowest levels of diversity). In addition to this, a significant signature of isolation by distance within the West clade and evidence of a population expansion event both reflect the recent recolonization of continental Europe by $R$. hipposideros from southern refugia following the LGM. The genetic diversity at the nuclear microsatellite level is concordant with the mtDNA analysis and showed that the highest levels of genetic diversity for this species are found in the refugial areas proposed by the mtDNA with lowest diversity in northwestern European populations. Whilst the timing of the formation of the refugial clades and population expansion could be tentatively dated, uncertainties in the mutation rates of markers incorporated into dating analysis require that any date estimations are taken with a degree of caution. Rates of molecular evolution have been shown to be lineage-specific, with two orders of magnitude variation in mutation rate reported within mammals for mitochondrial DNA (Nabholz et al. 2008). Rates of molecular evolution have also been shown to be time-dependent, with faster rates of evolution reported for several taxonomic groups in intermediate or recent timescales (Ho et al. 2011). If there has been a rapid decay in evolutionary mutation rate within this species similar to that described for humans (Henn et al. 2008), then all estimated dates in this analysis would be significantly more recent. Further divergence estimates based on larger and more diverse data sets will be required to fully corroborate these dates.

As predicted, $R$. hipposideros was found to have a similar phylogeographic history to $R$. ferrumequinum in that both species were shown to have an early colonization of Europe from the east, and both species used at least two Mediterranean glacial refugia during the ice age. However, $R$. hipposideros also differs from $R$. ferrumequinum: microsatellite data suggest that $R$. ferrumequinum recolonized Europe from two Mediterranean refugia, resulting in a single dominant mtDNA haplotype across Europe (Flanders et al. 2009). R. hipposideros in contrast has high levels of geographic structuring in the form of distinct mtDNA clades. This could result from aspects of the ecology of $R$. hipposideros: it is known to be a sedentary species with most seasonal movements between 5 and $20 \mathrm{~km}$ (Roer \& Schober 2001) with high roost fidelity and strong female philopatry. Alternatively, it might reflect the different genetic markers used in these two studies with faster evolving mtDNA regions detecting more finescale population structure (cytb-tRNA-control region was used in the present study whilst ND2 was used by Flanders et al. 2009). The Myotis nattereri (Natterer's bat) species complex has shown a similar phylogeographic pattern across Europe to $R$. hipposideros including refugia-within-refugia and refugia in the Maghreb and Mediterranean islands (Puechmaille et al. 2012a; Salicini et al. 2013). In general, the phylogeographic pattern displayed by $R$. hipposideros follows the grasshopper paradigm (Cooper et al. 1995) and is similar to small mammal species studied to date (bank vole, European snow vole, common shrew; Deffontaine et al. 2005; Castiglia et al. 2009; Bilton et al. 1998). Many European mammal species have also been found to have refugia in Anatolia or further east (hedgehog, lesser whitetoothed shrew; Santucci et al. 1998; Taberlet et al. 1998). Interestingly, $R$. hipposideros is also somewhat similar to the tawny owl (Brito 2005): like $R$. hipposideros a sedentary, nonmigratory species associated with deciduous woodland. The tawny owl used all Mediterranean refugia, in addition to north African and eastern refugia, but recolonized Europe from Balkans alone.

The findings of this study should be used to inform conservation management of this species. Because the refugial areas harbour the highest levels of genetic diversity, they should be of high conservation priority. 
Rebelo et al. (2010) found that species such as R. hipposideros will likely undergo range expansions northwards in the short term in response to climatic changes. However, by the end of the century, the Mediterranean peninsulas may become unsuitable for this species, and in the worst case scenario (a fossil fuel intensive model; Nakicenovic \& Swart 2000), the extinction of populations in southern Europe is predicted. This prediction does not take into account roost availability (one of the most limiting resources for bats) or specific foraging habitat requirements. R. hipposideros is, however, a highly adaptable species, surviving in vastly different habitat types from the semidesert areas of Sinai to the temperate wooded areas of Ireland and utilizes different roost types across this range (Dietz et al. 2009). Supposing more moderate levels of climate change, the long-term conservation of this species will still rely upon appropriate roost provision/protection and effective habitat management.

\section{Conclusions}

In summary, all three data sets indicate high levels of genetic diversity in the east of the species range. In agreement with fossil data, the nuclear intron data provide evidence for an ancient colonization of Europe by this species pre-dating the Quaternary ice ages and illustrates that the origin of this species is from the Middle East/Asia Minor. During the Pleistocene, $R$. hipposideros utilized multiple refugia across the Mediterranean in addition to an eastern refugium and recolonized central and northern Europe from either the Balkan refugium and/or from more recently formed and short-lived refugia in the northern part of the Mediterranean (e.g. Southern France, Northern Italy). Whilst the microsatellite data are not used directly to infer phylogeography, they are used to estimate modern day population differentiation for groups which had shown divergence at the mtDNA level. This study further illustrates the importance and benefits of utilizing a multi-marker approach when addressing phylogeographic questions.

\section{Acknowledgements}

We thank our colleagues for donating or helping to collect samples used in this study: members of the Groupe Chiroptères de Bourgogne, members of Galanthus Assoc. Catalonia, Association Sportive de Spéléologie d'Agadir (Morocco), the Society for the Protection of Prespa (SPP), Emmanuel Cosson, Maria Jerabek, François Catzeflis, Mara Calvini, Martina Spada, Benjamin Allegrini, Awatef Abiadh, Yannis Kazoglou, Elena Papadatou, Xavier Grémillet, Charlotte Roemer, Ivailo Borissov, Paolo Agnelli, Petr Benda, Conor Kelleher, Kate McAney, Saoirse McHugh, Daniel Buckley, Eileen O'Keefe, Clare Heard- man, Liam Lenihan, Sinead Biggane, Raymond Stephens, Kathryn Freeman and Maurice McDonnell. Sample collection was carried out under permits from: English Nature, the Countryside Council for Wales, the National Parks and Wildlife Service in Ireland (Permit no. C18/2008), the Greek Ministry of Agricultural Development and Food (Permit No. 104694/2439, 91306/1807, 94728/1025, 98358/1437, 97371/2554) French Direction Régionale de l'Environnement, de l'Aménagement et du Logement (Arrêté $\mathrm{n}^{\circ}$ 2009-11), Consejeria de Fomento y Medio Ambiente-Ceuta Exp. 32093/2 (2001), Direccion Gral Medio Ambiente-Extremadura (Res. 24/02/2004), Direccion Gral del Medio Natural-La Rioja (Res. S-18320 09/08/2001), Direccion Gral Gestion del Medio Natural-Andalucia (Res. 02/ 06/2003), L-Awtorità ta' Malta Dwar l-Ambjent u l-Ippjanar (Permit No. NP00068/09), Bulgaria (05-08-3096, 15-RD-08/ 15.01.2001，48-00-56/16.01.2001，8/02.07.2004 RIOSV Pleven, RIOSV Ruse), Slovenia (35601-71/2008-4) and Israel (2007/ 28417). This research was supported by a grant from the Irish Research Council for Science, Engineering and Technology and University College Dublin, Seed Funding to S. Dool and E.C. Teeling. S. Rossiter was supported by a Royal Society University Research Fellowship, G. Jones by Countryside Council for Wales funding, E. Petit by the Région Bretagne and S. Puechmaille by an 'IRCSET-Marie Curie International Mobility Fellowship in Science, Engineering and Technology'. We thank three anonymous reviewers for their constructive suggestions.

\section{References}

Antao T, Lopes A, Lopes RJ, Beja-Pereira A, Luikart G (2008) LOSITAN: a workbench to detect molecular adaptation based on a Fst-outlier method. BMC Bioinformatics, 9, 323-327.

Arbogast BS, Kenagy GJ (2001) Comparative phylogeography as an integrative approach to historical biogeography. Journal of Biogeography, 28, 819-825.

Balloux F (2010) The worm in the fruit of the mitochondrial DNA tree. Heredity, 104, 419-420.

Bandelt HJ, Forster P, Rohl A (1999) Median-joining networks for inferring intraspecific phylogenies. Molecular Biology and Evolution, 16, 37-48.

Beaumont MA, Nichols RA (1996) Evaluating loci for use in the genetic analysis of population structure. Proceedings of the Royal Society of London, B, 263, 1619-1626.

Bermingham E, Moritz C (1998) Comparative phylogeography: concepts and applications. Molecular Ecology, 7, 367-369.

Bilgin R, Coraman A, Karatas A, Morales J (2009) Phylogeography of the greater horseshoe bat, Rhinolophus ferrumequinum (Chiroptera: Rhinolophidae), in southeastern Europe and Anatolia, with a specific focus on whether the Sea of Marmara is a barrier to gene flow. Acta Chiropteralogica, 11, 53-60.

Bilton DT, Mirol PM, Mascheretti S et al. (1998) Mediterranean Europe as an area of endemism for small mammals rather than a source for northwards postglacial colonization. Proceedings of the Royal Society B: Biological Sciences, 265, 1219-1226.

Biollaz F, Bruyndonckx N, Beuneux G et al. (2010) Genetic isolation of insular populations of the Maghrebian bat, Myotis punicus, in the Mediterranean Basin. Journal of Biogeography, 37, 1557-1569.

Boston ESM, Puechmaille SJ, Scott DD et al. (2012) Empirical assessment of non-invasive population genetics in bats: com- 
parison of DNA quality from faecal and tissue samples. Acta Chiropterologica, 14, 45-52.

Brito PH (2005) The influence of Pleistocene glacial refugia on tawny owl genetic diversity and phylogeography in western Europe. Molecular Ecology, 14, 3077-3094.

Castella V, Ruedi M, Excoffier L et al. (2000) Is the Gibraltar strait a barrier to gene flow for the bat Myotis myotis (Chiroptera: Vespertilionidae)? Molecular Ecology, 9, 1761-1772.

Castiglia R, Annesi F, Krystufek M, Filippucci MG, Amori G (2009) The evolutionary history of a mammal species with a highly fragmented range: the phylogeography of the European snow vole. Journal of Zoology, 279, 243-250.

Centeno-Cuadros A, Delibes M, Godoy JA (2009) Phylogeography of Southern Water Vole (Arvicola sapidus): evidence for refugia within the Iberian glacial refugium? Molecular Ecology, 18, 3652-3667.

Cooper SJB, Ibrahim KM, Hewitt GM (1995) Postglacial expansion and genome subdivision in the European grasshopper Chorthippus parallelus. Molecular Ecology, 4, 49-60.

Cosson JF, Hutterer R, Libois R et al. (2005) Phylogeographic footprints of the Strait of Gibraltar and Quaternary climatic fluctuations in the western Mediterranean: a case study with the greater white-toothed shrew, Crocidura russula (Mammalia: Soricidae). Molecular Ecology, 14, 1151-1162.

Crawford NG (2009) SMOGD: software for the measurement of genetic diversity. Molecular Ecology Resources, 10, 556-557.

Csorba G, Ujhelyi P, Thomas N (2003) Horseshoe Bats of the World: (Chiroptera: Rhinolophidae). Alana Books, Bishop's Castle, Shropshire.

Darriba D, Taboada GL, Doallo R, Posada D (2012) jModelTest 2: more models, new heuristics and parallel computing. Nature Methods, 9, 772.

Deffontaine V, Libois R, Kotlik P et al. (2005) Beyond the Mediterranean peninsulas: evidence of central European glacial refugia for a temperate forest mammal species, the bank vole (Clethrionomys glareolus). Molecular Ecology, 14, 1727-1739.

Dietz C, Von Helversen O, Nill D (2009) Bats of Britain, Europe \& Northwest Africa. A \& C Black Publishers Ltd., London.

Dray S, Dufour AB (2007) The ade4 package: implementing the duality diagram for ecologists. Journal of statistical software, 22, 1-20.

Drummond AJ, Rambaut A (2007) BEAST: Bayesian evolutionary analysis by sampling trees. BMC Evolutionary Biology, 7, 214-221.

Earl DA, Louie KD, Bardeleben C, Swift CC, Jacobs DK (2010) Rangewide microsatellite phylogeography of the endangered tidewater goby, Eucyclogobius newberryi (Teleostei: Gobiidae), a genetically subdivided coastal fish with limited marine dispersal. Conservation Genetics, 11, 103-114.

Eckert AJ (2011) Seeing the forest for the trees: statistical phylogeography in a changing world. New Phytologist, 189, 894-897.

Emerson BC, Hewitt GM (2005) Phylogeography. Current biology, 15, 367-371.

Excoffier L, Lischer HEL (2010) Arlequin suite ver 3.5: a new series of programs to perform population genetics analyses under Linux and Windows. Molecular Ecology Resources, 10, 564-567.

Flanders J, Jones G, Benda P et al. (2009) Phylogeography of the greater horseshoe bat, Rhinolophus ferrumequinum: contrasting results from mitochondrial and microsatellite data. Molecular Ecology, 18, 306-318.
Flanders J, Wei L, Rossiter SJ, Zhang S (2011) Identifying the effects of the Pleistocene on the greater horseshoe bat, Rhinolophus ferrumequinum, in East Asia using ecological niche modelling and phylogenetic analyses. Journal of Biogeography, 38, 439-452.

Fulton TL, Strobeck C (2010) Multiple markers and multiple individuals refine true seal phylogeny and bring molecules and morphology back in line. Proceedings of the Royal Society B: Biological Sciences, 277, 1065-1070.

Gaisler J (1966) Reproduction in the lesser horseshoe bat (Rhinolophus hipposideros hipposideros Bechstein, 1800). Bijdragen tot de Dierkunde, 36, 45-64.

Galtier N, Nabholz B, Glemin S, Hurst GDD (2009) Mitochondrial DNA as a marker of molecular diversity: a reappraisal. Molecular Ecology, 18, 4541-4550.

Garcia-Mudarra JL, Ibañez C, Juste J (2009) The straits of Gibraltar: barrier or bridge to Ibero-Moroccan bat diversity? Biological Journal of the Linnean Society, 96, 434-450.

Gaubert P, Machordom A, Morales A et al. (2011) Comparative phylogeography of two African carnivorans presumably introduced into Europe: disentangling natural versus human-mediated dispersal across the Strait of Gibraltar. Journal of Biogeography, 38, 341-358.

Godinho R, Crespo EG, Ferrand N (2008) The limits of mtDNA phylogeography: complex patterns of population history in a highly structured Iberian lizard are only revealed by the use of nuclear markers. Molecular Ecology, 17, 4670-4683.

Gómez A, Lunt DH (2007) Refugia within refugia: patterns of phylogeographic concordance in the Iberian Peninsula. In: Phylogeography in Southern European Refugia: Evolutionary Perspectives on the Origins and Conservation of European Biodiversity (eds Weiss S, Ferrand N), pp. 155-188. Springer, Dordrecht, the Netherlands.

Goslee SC, Urban DL (2007) The ecodist package for dissimilarity-based analysis of ecological data. Journal of Statistical Software, 22, 1-19.

Goudet J (2001) FSTAT, a program to estimate and test gene diversities and fixation indices (version 2.9.3.2).

Guindon S, Gascuel O (2003) A simple, fast, and accurate algorithm to estimate large phylogenies by maximum likelihood. Systematic biology, 52, 696-704.

Henn BM, Gignoux CR, Feldman MW, Mountain JL (2008) Characterizing the time dependency of human mitochondrial DNA mutation rate estimates. Molecular Biology and Evolution, 26, 217-230.

Hewitt GM (1999) Post-glacial re-colonization of European biota. Biological Journal of the Linnean Society, 68, 87-112.

Hewitt GM (2004) Genetic consequences of climatic oscillations in the Quaternary. Philosophical Transactions of the Royal Society London B, 359, 183-195.

Hickerson MJ, Carstens BC, Cavender-Bares J et al. (2010) Phylogeography's past, present, and future: 10 years after Avise, 2000. Molecular Phylogenetics and Evolution, 54, 291-301.

Ho SYW, Lanfear R, Bromham L et al. (2011) Time-dependent rates of molecular evolution. Molecular ecology, 20, 3087-3101.

Hurst GDD, Jiggins FM (2005) Problems with mitochondrial DNA as a marker in population, phylogeographic and phylogenetic studies: the effects of inherited symbionts. Proceedings of the Royal Society B, 272, 1525-1534.

Jacobs D, Cotterill FPD, Taylor PJ et al. (2008) Rhinolophus hipposideros. In: IUCN 2012. IUCN Red List of Threatened Species. Version 2012.2. www.iucnredlist.org. 
Jombart T (2008) adegenet: a $\mathrm{R}$ package for the multivariate analysis of genetic markers. Bioinformatics, 24, 1403-1405.

Jost L (2008) GST and its relatives do not measure differentiation. Molecular Ecology, 17, 4015-4026.

Juste J, Ibañez C, Muñoz J et al. (2004) Mitochondrial phylogeography of the long-eared bats (Plecotus) in the mediterranean Palearctic and Atlantic Islands. Molecular Phylogenetics and Evolution, 31, 1114-1126.

Kotlik P, Deffontaine V, Mascheretti S et al. (2006) A northern glacial refugium for bank voles (Clethrionomys glareolus). Proceedings of the National Academy of Sciences of the United States of America, 103, 14860-14864.

Laslett D, Canback B (2008) ARWEN: a program to detect tRNA genes in metazoan mitochondrial nucleotide sequences. Bioinformatics, 24, 172-175.

Lyons LA, Laughlin TF, Copeland NG et al. (1997) Comparative anchor tagged sequences (CATS) for integrative mapping of mammalian genomes. Nature Genetics, 15, 47-56.

Manni F, Guerard E, Heyer E (2004) Geographic patterns of (genetic, morphologic, linguistic) variation: how barriers can be detected by using Monmonier's algorithm. Human Biology, 76, 173-190.

Mao X, He G, Hua P et al. (2013) Historical introgression and the persistence of ghost alleles in the intermediate horseshoe bat (Rhinolophus affinis). Molecular Ecology, 22, 10351050.

Martins F, Templeton A, Pavan A, Kohlbach B, Morgante J (2009) Phylogeography of the common vampire bat (Desmodus rotundus): marked population structure, Neotropical Pleistocene vicariance and incongruence between nuclear and mtDNA markers. BMC evolutionary biology, 9, 294-307.

Meredith RW, Janecka JE, Gatesy J et al. (2011) Impacts of the Cretaceous Terrestrial Revolution and $\mathrm{KPg}$ extinction on mammal diversification. Science, 334, 521-524.

Mitchell-Jones AJ (1995) The status and conservation of horseshoe bats in Britain. Myotis, 32, 271-284.

Nabholz B, Glemin S, Galtier N (2008) Strong variations of mitochondrial mutation rate across mammals-the longevity hypothesis. Molecular Biology and Evolution, 25, 120-130.

Nakicenovic N, Swart R (2000) Emission Scenarios: A Special Report of Working Group III of the Intergovernmental Panel on Climate Change. Cambridge University Press, Cambridge.

Palmeirim JM (1990) Bats of Portugal: Zoogeography and Biosystematics. University of Kansas. Museum of Natural History, Lawrence, Kansas.

Pesole G, Gissi C, De Chirico A, Saccone C (1999) Nucleotide substitution rate of Mammalian mitochondrial genomes. Journal of Molecular Evolution, 48, 427-434.

Petit RJ, Hampe A, Cheddadi R (2005) Climate changes and tree phylogeography in the Mediterranean. Taxon, 54, 877885.

Puechmaille SJ, Petit EJ (2007) Empirical evaluation of noninvasive capture-mark-recapture estimates of population size based on a single sampling session. Journal of Applied Ecology, 44, 843-852.

Puechmaille SJ, Mathy G, Petit E (2005) Characterization of 14 polymorphic microsatellite loci for the lesser horseshoe bat, Rhinolophus hipposideros (Rhinolophidae, Chiroptera). Molecular Ecology Notes, 5, 941-944.

Puechmaille SJ, Mathy G, Petit EJ (2007) Good DNA from bat droppings. Acta Chiropterologica, 9, 269-276.
Puechmaille SJ, Gouilh MA, Piyapan P et al. (2011) The evolution of sensory divergence in the context of limited gene flow in the bumblebee bat. Nature Communications, 2, 573.

Puechmaille SJ, Allegrini B, Boston ESM et al. (2012a) Genetic analyses reveal further cryptic lineages within the Myotis nattereri species complex. Mammalian Biology, 77, 224-228.

Puechmaille SJ, Hizem WM, Allegrini B, Abiadh A (2012b) Bat fauna of Tunisia: review of records and new records, morphometrics and echolocation data. Vespertilio, 16, 211-239.

Puerma E, Acosta MJ, Barragán MJL et al. (2008) The karyotype and 5S rRNA genes from Spanish individuals of the bat species Rhinolophus hipposideros (Rhinolophidae; Chiroptera). Genetica, 134, 287-295.

R Development Core Team (2012) R: A Language and Environment for Statistical Computing. R Foundation for Statistical Computing, Vienna, Austria. Available at: http://cran.rproject.org/.

Rambaut A (1996) Se-Al, A Manual Sequence Alignment Editor, version v4.5 Oxford University, Oxford, England.

Rambaut A, Drummond AJ (2007) Tracer v1.4, Available from http:/ / beast.bio.ed.ac.uk/Tracer

Randi E (2007) Phylogeography of south European mammals. In: Phylogeography of Southern European Refugia: Evolutionary Perspectives on the Origins and Conservation of European Biodiversity (eds Weiss S, Ferrand N), pp. p.101-126. Springer, Dordrecht, Netherlands.

Rebelo H, Tarroso P, Jones G (2010) Predicted impact of climate change on European bats in relation to their biogeographic patterns. Global Change Biology, 16, 561-576.

Rodríguez F, Pérez T, Hammer SE, Albornoz J, Domínguez A (2010) Integrating phylogeographic patterns of microsatellite and mtDNA divergence to infer the evolutionary history of chamois (genus Rupicapra). BMC Evolutionary Biology, 10, 222-241.

Roer H, Schober W (2001) Rhinolophus hipposideros (Bechstein 1800) - Kleine Hufeisennase. In: Handbuch der Säugetiere Europas, Band 4: Fledertiere. Chiroptera I: Rhinolophidae, Vespertilionidae 1 (ed Krapp F), pp. 40-53. AULA-Verlag, Wiebelsheim, Germany.

Rogers AR, Harpending H (1992) Population growth makes waves in the distribution of pairwise genetic differences. Molecular Biology and Evolution, 9, 552-569.

Rossiter SJ, Benda P, Dietz C, Zhang S, Jones G (2007) Rangewide phylogeography in the greater horseshoe bat inferred from microsatellites: implications for population history, taxonomy and conservation. Molecular Ecology, 16, 4699-4714.

Ruedi M, Walter S, Fischer MC et al. (2008) Italy as a major ice age refuge area for the bat Myotis myotis (Chiroptera: Vespertilionidae) in Europe. Molecular Ecology, 17, 1801-1814.

Salicini I, Ibáñez C, Juste J (2013) Deep differentiation between and within Mediterranean glacial refugia in a flying mammal, the Myotis nattereri bat complex. Journal of Biogeography, 40, 1182-1193.

Santucci F, Emerson BC, Hewitt GM (1998) Mitochondrial DNA phylogeography of European hedgehogs. Molecular Ecology, 7, 1163-1172.

Sbisà E, Tanzariello F, Reyes A, Pesole G, Saccone C (1997) Mammalian mitochondrial D-loop region structural analysis: identification of new conserved sequences and their functional and evolutionary implications. Gene, 205, 125-140.

Schenekar T, Weiss S (2011) High rate of calculation errors in mismatch distribution analysis results in numerous false inferences of biological importance. Heredity, 107, 511-512. 
Spinks PQ, Thomson RC, Bradley Shaffer H (2010) Nuclear gene phylogeography reveals the historical legacy of an ancient inland sea on lineages of the western pond turtle, Emys marmorata in California. Molecular Ecology, 19, 542-556.

Stephens M, Donnelly P (2003) A comparison of Bayesian methods for haplotype reconstruction from population genotype data. The American Journal of Human Genetics, 73, 11621169.

Storch G (1974) Quartäre Fledermaus-Faunen von der Insel Malta. Senckenbergiana lethaia, 55, 407-434.

Strandberg G, Brandefelt J, Kjellstrom E, Smith B (2011) High resolution regional simulation of last glacial maximum climate in Europe. Tellus A, 63, 107-125.

Struebig MJ, Kingston T, Petit EJ et al. (2011) Parallel declines in species and genetic diversity in tropical forest fragments. Ecology Letters, 14, 582-590.

Taberlet P, Fumagalli L, Wust-Saucy AG (1998) Comparative phylogeography and postglacial colonization routes in Europe. Molecular Ecology, 7, 453-464.

Tamura K, Peterson D, Peterson N et al. (2011) MEGA5: molecular evolutionary genetics analysis using maximum likelihood, evolutionary distance, and maximum parsimony methods. Molecular biology and evolution, 28, 27312739.

Ursenbacher S, Schweiger S, Tomovic L et al. (2008) Molecular phylogeography of the nose-horned viper (Vipera ammodytes, Linnaeus (1758)): evidence for high genetic diversity and multiple refugia in the Balkan Peninsula. Molecular Phylogenetics and Evolution, 46, 1116-1128.

Van Oosterhout C, Hutchison WF, Wills DPM, Shipley P (2004) MICRO-CHECKER: software for identifying and correcting genotyping errors in microsatellite data. Molecular Ecology Notes, 4, 535-538.

Vega R, Fløjgaard C, Lira Noriega A et al. (2010) Northern glacial refugia for the pygmy shrew Sorex minutus in Europe revealed by phylogeographic analyses and species distribution modelling. Ecography, 33, 260-271.

Villesen P (2007) FaBox: an online toolbox for fasta sequences. Molecular Ecology Notes, 7, 965-968.

Weir BS, Cockerham CC (1984) Estimating F-statistics for the analysis of population structure. Evolution, 38, 1358-1370.

Zima J, Volleth M, Horácek I et al. (1992) Comparative karyology of rhinolophid bats (Chiroptera: Rhinolophidae). In: Prague Studies in Mammalogy (eds Horácek I \& Vohralik V), pp. 229-236. Charles University Press, Praha.

E. C. T. and S. J. R. conceived the study. E. C. T. supervised the project. S. J. R. supervised the microsatellite laboratory work in London. S. E. D. collected genetic samples, generated the genetic data and performed analysis. S. J. P. contributed to analysis and figure preparation. S. E. D. and E. C. T. wrote the paper. All authors (S. E. D., S. J. R., S. J. P, C. D., J. J., C. I., P. H., S. G. R., E. J. P., G. J., D. R., R. T., A. V., A. M., E. C. T.) provided genetic samples and commented on the manuscript.

\section{Data accessibility}

DNA sequences: GenBank Accessions: KC978344KC978716 mtDNA; KC978153-KC978343 nuclear intron data; KC978717 microsatellite sequence Rha109. Supporting Information Table S7: individual genotypes at eight microsatellite loci. Supporting Information Table S8: individual sampling details of Rhinolophus hipposideros used in this study.

\section{Supporting information}

Additional supporting information may be found in the online version of this article.

Fig. S1 Mitochondrial primer schematic. Arrows indicate the primer pairs used in this study to amplify two over-lapping fragments (cytb: mtDNA-R3-F/mtDNA-F3-R, shown in red; partial control region: mtDNA-R2-F/mtDNA-F2-R, shown in blue).

Table S1 Molecular diversity indices for Bgn intron 4 in R. hipposideros. (N) number of individuals, (nh) number of haplotypes, (Pi) mean pairwise differences, $(\mathrm{h})$ haplotype and $(\pi)$ nucleotide diversities. Sample sites are coloured according to geographic origin (see Fig. 3).

Table S2 Molecular diversity indices for mtDNA in $R$. hipposideros. (N) number of individuals, (nh) number of haplotypes, (Pi) mean pairwise differences, (h) haplotype and $(\pi)$ nucleotide diversities. Sample sites are coloured according to geographic origin (see Fig. 4). Values are reported for each country and for supported clades (in bold; see Fig. 4).

Table S3 Pairwise $\Phi$ st values between supported mtDNA clades of $R$. hipposideros (lower diagonal) with associated $\mathrm{P}$ values (upper diagonal). Significant values $(<0.05)$ are highlighted in bold.

Table S4 Estimates of divergence times of supported mtDNA clades of Rhinolophus hipposideros. BPP, Bayesian Posterior Probability. tmrca, (time to most recent common ancestor) statistic generated from BEAST phylogenetic analysis (Fig. 4). HPD, (Highest Posterior Density), a credible set that contains $95 \%$ of the sampled values. Geological series \& stage (Cohen \& Gibbard 2011 Global chronostratigraphical correlation table for the last 2.7 million years. Subcommission on Quaternary Stratigraphy International Commission on Stratigraphy, Cambridge, England).

Table S5 Genetic diversity indices for 8 microsatellite loci in populations of R. hipposideros. Site (see Table 1, Fig. 1), N (number of individuals), $\mathrm{H}_{\mathrm{E}}, \mathrm{H}_{\mathrm{O}}$ (expected and observed heterozygosity), FIS (inbreeding coefficient), R (allelic richness; based on a minimum sample size of 3 diploid individuals). Sample sites are coloured according to geographic origin (see Fig. $3 \& 4$ ).

Table S6 Estimates of genetic differentiation based on microsatellite loci in populations of Rhinolophus hipposideros in Europe, the Middle East and North Africa based on Dest (Jost 2008); (For population identity see Table S5).

Table S7 Individual genotypes for Rhinolophus hipposideros at eight microsatellite loci.

Table S8 Sampling details and GenBank accessions for all Rhinolophus hipposideros used in the current study. 